\title{
Efficiency of sea buckthorn extract in oxidative stability improvement of high oleic sunflower oil
}

\author{
M. Mardani ${ }^{1 *}$ (i), L. Somogyi ${ }^{1}$, I. Szedljak ${ }^{1}$, I. Prauda ${ }^{2}$, J. Farmani ${ }^{3}$ and \\ K. Badakné Kerti ${ }^{1}$
}

\begin{abstract}
${ }^{1}$ Department of Cereal and Industrial Plant Processing, Institute of Food Science and Technology, Hungarian University of Agriculture and Life Sciences, Villányi út 23, H-1118 Budapest, Hungary

${ }^{2}$ Department of Food Chemistry and Nutrition Science, Institute of Food Science and Technology, Hungarian University of Agriculture and Life Sciences, Somlói út 14-16, H-1118 Budapest, Hungary

${ }^{3}$ Department of Food Science and Technology, Faculty of Agricultural Engineering, Sari Agricultural Sciences and Natural Resources University, PO Box: 578, Sari, Iran
\end{abstract}

\section{ORIGINAL RESEARCH PAPER}

\section{ABSTRACT}

Sea buckthorn (Hippophae rhamnoides) with high antioxidant capacity is distributed all over the world, but has never been used as a natural antioxidant in oils to replace synthetic antioxidants. Therefore, this study was performed to investigate the effectiveness of sea buckthorn extract in comparison to a common natural antioxidant rosemary extract and a synthetic antioxidant on retarding lipid oxidation. First the extracts were characterised, and it was found that sea buckthorn extract had higher polyphenol contents, radical scavenging activity, and higher antioxidant capacity. Then the proper concentrations for the use of these antioxidants were determined. Additionally, the progress of lipid oxidation during cycles of frying was assessed in terms of free fatty acids content, peroxide value, $p$-anisidine value, TOTOX value, colour, total polar compounds, and Induction period. The general order of effectiveness for inhibition of high oleic sunflower oil degradation during frying was: sea buckthorn $>$ BHT $>$ rosemary $>$ control $(P<0.05)$.

\section{KEYWORDS}

sea buckthorn, rosemary, oxidative stability, high oleic sunflower oil

*Corresponding author. E-mail: Mohsen.mardani.h@gmail.com 


\section{INTRODUCTION}

Traditionally, synthetic antioxidants are added to frying oils to reduce their oxidative deterioration (Shahidi and Ambigaipalan, 2015). However, the application of synthetic antioxidants has been restricted because of their potential carcinogenic effects and toxicity (Hou, 2003). Therefore, there is a trend in consumer preference for natural ingredients, such as phenolic compounds found in plants instead of synthetic compounds, which are still being used in the food industry (Yang et al., 2016; Wu et al., 2019). Bioactive components such as phenolics and flavonoids of plants tend to exhibit free radical scavenging activity, so they can be exploited in searching for novel antioxidants (Shahidi and Ambigaipalan, 2015).

Sea buckthorn (SBT) is a bush species with high radical scavenging activity (Negi et al., 2005; Papuc et al., 2008), but it has never been used as a natural antioxidant to improve the oxidative properties of frying oils. Therefore, the purpose of the current investigation was to evaluate the effectiveness of SBT extract during the frying process of high oleic sunflower oil in comparison with rosemary extract as a common natural extract and BHT as a common synthetic antioxidant. The most suitable concentration of these extracts added into the oil was also investigated.

\section{MATERIALS AND METHODS}

\subsection{Materials}

Refined high oleic sunflower oil (HOSO) with no antioxidant content was gifted by Bunge Zrt., Hungary. The SBT plant (flesh) and rosemary plant (leaves) were obtained from Bio-Drog-Berta $\mathrm{Kft}$., Hungary and dried at $80^{\circ} \mathrm{C}$. Butylated hydroxytoluene (BHT) was purchased from SigmaAldrich. All other chemicals used in this study were of analytical grade.

\subsection{Preparation of extracts}

Extraction was done with slight modification based on a method described by Da Porto et al. (2013). In summary, $10 \mathrm{~g}$ of powdered plant was mixed with $100 \mathrm{~mL}$ of methanol and sonicated at $35 \mathrm{kHz}$ for $1 \mathrm{~h}$ at $30^{\circ} \mathrm{C}$. Then it was kept for $24 \mathrm{~h}$ at room temperature with intermittent shaking. The mixture was filtered, and the solvent was evaporated. The resulting residue was further dried in an atmospheric pressure oven to ensure the removal of any residual solvent and was stored at $-18^{\circ} \mathrm{C}$ till use. The final extract was a dark green powder.

\subsection{Characterisation of the extracts}

2.3.1. Polyphenols content. The total phenol content was determined using Folin-Ciocalteu reagent (FCR) according to Singleton et al. (1999). The concentration was measured with gallic acid, and values are reported in gallic acid equivalents per gram extract (GAE/g).

2.3.2. FRAP assay. The method is based on the reduction of the ferric tripyridyltriazine $\left(\mathrm{Fe}^{3+}\right.$ TPTZ) complex to the ferrous tripyridyltriazine $\left(\mathrm{Fe}^{2+}-\mathrm{TPTZ}\right)$ at low $\mathrm{pH}$. This reduction is monitored by measuring the absorption change at $593 \mathrm{~nm}$. FRAP values were obtained by comparing the absorption change in the test mixture as described by Benzie and Strain (1996). 
2.3.3. DPPH assay. The antioxidant activity of extracts was evaluated by determining the antiradical activity of the sample against the radical 2,2-diphenyl-1-picrylhydrazyl (DPPH) according to $\mathrm{Xu}$ and Chang (2007).

\subsection{Frying tests}

2.4.1. Determination of concentration. Antioxidants were added into the oil at different concentrations $(100,200,400,600,800$, and 1,000 ppm) selected based on a literature review (Wu et al., 2019). Oil samples containing the desired concentration of antioxidants were subjected to frying at $180 \pm 2{ }^{\circ} \mathrm{C}$ for 15 cycles (each cycle $5 \mathrm{~min}$ ), and samples were drawn at the end of this period. Samples were taken for free fatty acids content, peroxide value, $p$-anisidine value, and Totox value determinations.

2.4.2. Effect of frying cycles. Extracts were added to the oil at their optimum concentration (400 ppm as determined in the previous step) and were subjected to frying at $180 \pm 2{ }^{\circ} \mathrm{C}$ for 15 cycles (each cycle $5 \mathrm{~min}$ ). Sampling was done from every three batches $\left(3^{\text {rd }}, 6^{\text {th }}, 9^{\text {th }}, 12^{\text {th }}\right.$, and $15^{\text {th }}$ ) till the end of frying (five times and control). Oil samples containing BHT at the maximum legally permitted level of $(200 \mathrm{ppm})$ and another with no added antioxidant were used as controls.

2.4.2.1. Total polar compounds (TPC). Testo 270 Deep-frying Oil Tester (Testo Inc., Germany) was used for the rapid measurement of the TPC level in oil samples during frying. The sensor calibration was done with an essential oil provided by the manufacturer.

2.4.2.2. Free fatty acids (FFA). FFA content as a percentage of oleic acid was determined by AOCS Official Method Ca 5a-40 (AOCS, 1998).

2.4.2.3. Peroxide value (PV). PV was determined by AOCS Official Method Cd 8-53 (AOCS, 1998).

2.4.2.4. $\mathbf{p}$-Anisidine value (p-AnV). $p$-AnV was determined by AOCS Official Method CC 8-11 (AOCS, 1998).

2.4.2.5. Totox value. TV value was expressed as $2 \mathrm{PV}+p$-AnV.

2.4.2.6. Colour analysis. The colours of the samples were analysed using CR-310 Chroma Meter (Konica Minolta, Japan). The instrument was calibrated using the standard white tile ( $\mathrm{L}^{*}$ 98.03, $\mathrm{a}^{*}-0.23$, and $\left.\mathrm{b}^{*} 0.25\right)$.

2.4.2.7. Induction time. An automated rancimat instrument (Model 743, Metrohm Herisau, Switzerland) was used to test the oxidative stability of the oil samples. The accelerated oxidation conditions in the oil samples $(5 \mathrm{~g})$ were established using an airflow rate of $20 \mathrm{~L} \mathrm{~h}^{-1}$ and $120^{\circ} \mathrm{C}$ (Upadhyay and Mishra, 2015).

\subsection{Statistical analysis}

Statistical analysis was carried out using two-way analysis of variance (ANOVA) and Tukey's as post hoc test when homogeneity of variances was accepted and Games-Howell when the 
homogeneity of variances was rejected using SPSS software IMB SPSS-25. Significant levels were based on the confidence level of $95 \%(P<0.05)$. Analyses and independent sampling were done in triplicates.

\section{RESULT AND DISCUSSION}

\subsection{Characterisation of extracts}

3.1.1. Polyphenols content. The phenolic content of the extracts was determined as 132 and $108 \mathrm{mg} \mathrm{GAE} / \mathrm{g}$ extract for SBT and rosemary, respectively. For rosemary extract, this amount was less than that found by Erkan et al. (2008) and Chammem et al. (2015) for methanolic rosemary extract, which were about $162 \mathrm{mg} \mathrm{GAE} / \mathrm{g}$ and $112 \mathrm{mg} \mathrm{GAE} / \mathrm{g}$ extract, respectively. For sea buckthorn, this amount varied from 89 to even 165 in different studies (Papuc et al., 2008; Kant et al., 2012). This difference can be explained by the different polarity of methanol used in this study compared to mixes of water and ethanol used by Papuc et al. (2008). In another similar study reported by Negi et al. (2005) for SBT, polyphenols content was reported to be higher when extracted with methanol compared to non-polar solvents (chloroform, ethyl acetate, acetone). Other factors may also affect the polyphenols composition of the extracts, such as genetics, the season of collection, and the maturity of the plant (Liu et al., 2007).

3.1.2. FRAP assay. The highest antioxidant activity was observed for SBT $\left(190.67 \mathrm{mg} \mathrm{TE} \mathrm{g}^{-1}\right.$ $\mathrm{DW}$ ), followed by BHT (170.97 $\left.\mathrm{mg} \mathrm{TE}^{-1} \mathrm{DW}\right)$ and rosemary leaves (142.97 $\mathrm{mg} \mathrm{TE}^{-1} \mathrm{DW}$ ). This was comparable to the results found by Rodríguez-Rojo et al. (2012). Rosemary extract presented lower antioxidant activity than synthetic antioxidants.

3.1.3. DPPH assay. The scavenging activity values of the extracts at $0.1 \%$ concentration of BHT, rosemary, and SBT were $68.23,71.88$, and $86.45 \%$, respectively. The antioxidant activity of SBT was significantly higher $(P<0.05)$ than that of rosemary and BHT. The result shows that the SBT extract acts as primary antioxidant. These findings are in agreement with other studies (Negi et al., 2005; Kant et al., 2012).

\subsection{Antioxidants concentration}

As shown in Fig. 1, the antioxidant efficiency of extracts was generally enhanced by the increase in concentrations. Although high antioxidant activity was noticed in extracts up to concentrations of $1,000 \mathrm{ppm}$, the increase was mostly not significant above the concentration of $400 \mathrm{ppm}$. Therefore, $400 \mathrm{ppm}$ of each natural antioxidant was chosen for further measurements during frying procedures defined as a minimum dosage of extract for achieving high oxidative stability.

\subsection{Frying procedures}

3.3.1. Total polar compounds (TPC). The level of TPC increased with the number of cycles $(P<0.05)$, which was in accordance with other studies (Urbančič et al., 2014). The order of increase in the TPC across the frying cycle was: control $>$ BHT $=$ rosemary extract $>$ SBT extract. As shown in Fig. 2, oil without antioxidant should be discarded after 12 batches of 

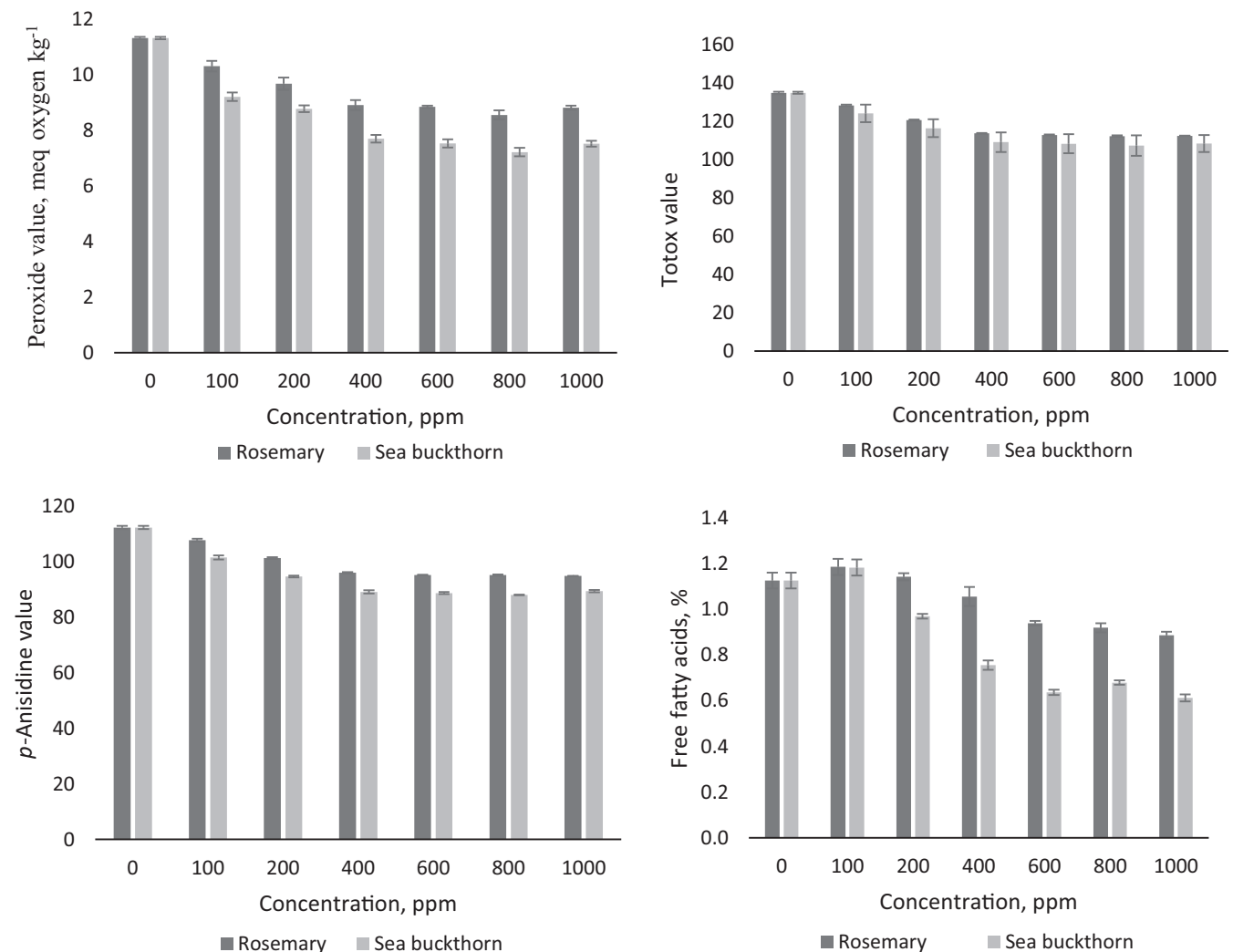

Fig. 1. Effects of antioxidant concentration on frying stability of high oleic sunflower oil samples with different antioxidants. Means for each antioxidant with different letters are significantly different $(P<0.05)$

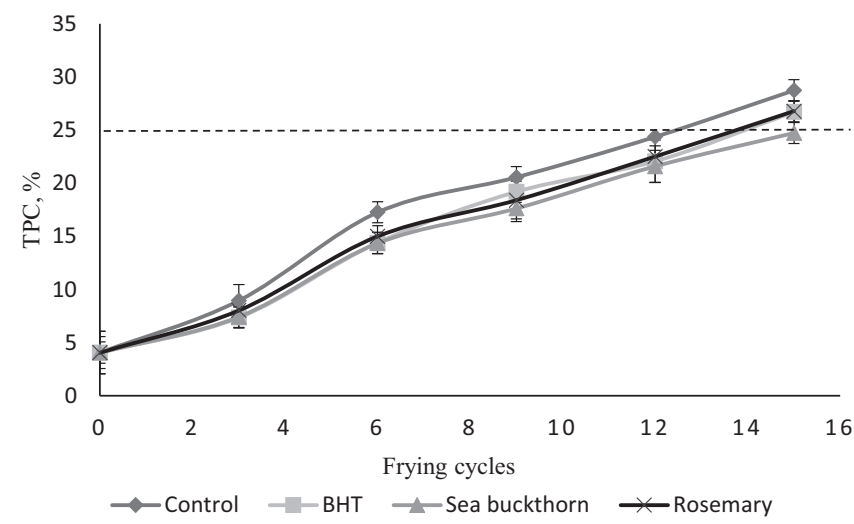

Fig. 2. Formation of TPC during frying of high oleic sunflower oil samples with different antioxidants 
frying, and the oil with the highest stability containing SBT extract should be discarded after 15 cycles.

3.3.2. Free fatty acids (FFA). The amount of FFA increased slowly during frying but did not exceed the limit of $2 \%$ established by European regulations (Firestone, 2009). At the end of the deep-frying process, the FFA contents of SBT and rosemary treatments were lower than those of the other treatments $(P<0.05)$, which is in accordance with other studies (Chammem et al., 2015; Guo et al., 2016).

3.3.3. Peroxide value (PV), $\mathrm{p}$-Anisidine value ( $\mathrm{p}-A n V)$, and Totox value. As shown in Table 1 , all antioxidants significantly $(P<0.05)$ reduced peroxide formation during frying. Generally, with an increase in the frying cycle, frying oils showed an increase in PV, followed by a slight decrease in the last cycle. Previous studies have also reported an initial PV increase during frying, followed by a later decrease (Poiana, 2012). SBT extract was the most effective and was superior to the commercial antioxidant mixture in preventing peroxide formation in vegetable oil.

Table 1. Quality changes of high oleic sunflower oil samples with different antioxidants

\begin{tabular}{crcccc}
\hline Characteristic & Cycles & Control & BHT & Sea buckthorn & Rosemary \\
\hline Free fatty & 0 & $0.09 \pm 0.01 \mathrm{aA}$ & $0.09 \pm 0.01 \mathrm{aA}$ & $0.09 \pm 0.01 \mathrm{aA}$ & $0.09 \pm 0.01 \mathrm{aA}$ \\
acid (\%) & 3 & $0.36 \pm 0.05 \mathrm{~dB}$ & $0.28 \pm 0.02 \mathrm{bB}$ & $0.18 \pm 0.03 \mathrm{aB}$ & $0.32 \pm 0.03 \mathrm{cB}$ \\
& 6 & $0.71 \pm 0.02 \mathrm{dC}$ & $0.60 \pm 0.02 \mathrm{cC}$ & $0.38 \pm 0.02 \mathrm{aC}$ & $0.50 \pm 0.03 \mathrm{bC}$ \\
& 9 & $0.96 \pm 0.03 \mathrm{dD}$ & $0.77 \pm 0.03 \mathrm{cD}$ & $0.54 \pm 0.03 \mathrm{aD}$ & $0.69 \pm 0.03 \mathrm{bD}$ \\
& 12 & $1.12 \pm 0.04 \mathrm{dE}$ & $0.88 \pm 0.03 \mathrm{cE}$ & $0.59 \pm 0.03 \mathrm{aDE}$ & $0.74 \pm 0.04 \mathrm{bE}$ \\
Peroxide & 15 & $1.13 \pm 0.01 \mathrm{dE}$ & $0.92 \pm 0.01 \mathrm{cF}$ & $0.60 \pm 0.04 \mathrm{aE}$ & $0.89 \pm 0.02 \mathrm{bF}$ \\
value (meq & 0 & $2.27 \pm 0.26 \mathrm{aA}$ & $2.27 \pm 0.26 \mathrm{aA}$ & $2.27 \pm 0.26 \mathrm{aA}$ & $2.27 \pm 0.26 \mathrm{aA}$ \\
oxygen/kg) & 3 & $5.98 \pm 0.14 \mathrm{cB}$ & $4.26 \pm 0.04 \mathrm{bB}$ & $3.87 \pm 0.46 \mathrm{aB}$ & $6.18 \pm 0.06 \mathrm{~dB}$ \\
& 6 & $7.92 \pm 0.49 \mathrm{dC}$ & $5.94 \pm 0.14 \mathrm{bC}$ & $5.03 \pm 0.08 \mathrm{aC}$ & $7.33 \pm 0.12 \mathrm{cC}$ \\
& 9 & $8.61 \pm 0.13 \mathrm{dD}$ & $6.58 \pm 0.08 \mathrm{aD}$ & $6.77 \pm 0.11 \mathrm{bD}$ & $7.98 \pm 0.14 \mathrm{cD}$ \\
p-Anisidine & 12 & $12.32 \pm 0.26 \mathrm{dE}$ & $8.00 \pm 0.12 \mathrm{bE}$ & $7.90 \pm 0.02 \mathrm{aF}$ & $9.17 \pm 0.07 \mathrm{cF}$ \\
value & 15 & $12.02 \pm 0.40 \mathrm{dE}$ & $8.74 \pm 0.20 \mathrm{cF}$ & $7.38 \pm 0.45 \mathrm{aE}$ & $8.73 \pm 0.34 \mathrm{bE}$ \\
& 0 & $8.89 \pm 0.51 \mathrm{aA}$ & $8.89 \pm 0.51 \mathrm{aA}$ & $8.89 \pm 0.51 \mathrm{aA}$ & $8.89 \pm 0.51 \mathrm{aA}$ \\
& 3 & $62.13 \pm 0.81 \mathrm{~dB}$ & $51.09 \pm 0.95 \mathrm{bB}$ & $47.85 \pm 0.38 \mathrm{aB}$ & $54.21 \pm 0.24 \mathrm{cB}$ \\
& 6 & $73.87 \pm 1.49 \mathrm{dC}$ & $60.19 \pm 0.77 \mathrm{aC}$ & $61.60 \pm 0.92 \mathrm{bC}$ & $62.00 \pm 0.74 \mathrm{cC}$ \\
& 9 & $85.70 \pm 1.16 \mathrm{dD}$ & $73.74 \pm 0.34 \mathrm{aD}$ & $75.52 \pm 1.12 \mathrm{bD}$ & $80.21 \pm 0.84 \mathrm{cD}$ \\
Totox & 12 & $95.80 \pm 0.67 \mathrm{dE}$ & $79.58 \pm 1.29 \mathrm{aE}$ & $80.34 \pm 0.96 \mathrm{bE}$ & $83.63 \pm 0.52 \mathrm{cE}$ \\
$(2 \mathrm{PV}+\mathrm{AnV})$ & 15 & $112.87 \pm 1.48 \mathrm{dF}$ & $92.19 \pm 0.33 \mathrm{bF}$ & $88.72 \pm 0.40 \mathrm{aF}$ & $94.56 \pm 1.18 \mathrm{cF}$ \\
& 0 & $13.43 \pm 0.55 \mathrm{aA}$ & $13.43 \pm 0.55 \mathrm{aA}$ & $13.43 \pm 0.55 \mathrm{aA}$ & $13.43 \pm 0.55 \mathrm{aA}$ \\
& 3 & $74.08 \pm 0.63 \mathrm{~dB}$ & $59.61 \pm 0.94 \mathrm{bB}$ & $55.58 \pm 0.87 \mathrm{aB}$ & $66.57 \pm 0.24 \mathrm{cB}$ \\
& 6 & $89.70 \pm 1.14 \mathrm{dC}$ & $72.07 \pm 0.79 \mathrm{bC}$ & $71.65 \pm 0.90 \mathrm{aC}$ & $76.65 \pm 0.88 \mathrm{cC}$ \\
& 9 & $104.93 \pm 5.00 \mathrm{dD}$ & $86.90 \pm 0.50 \mathrm{aD}$ & $89.06 \pm 0.90 \mathrm{bD}$ & $96.18 \pm 0.92 \mathrm{cD}$ \\
& 12 & $119.84 \pm 0.40 \mathrm{dE}$ & $95.59 \pm 1.27 \mathrm{aE}$ & $96.13 \pm 1.00 \mathrm{bE}$ & $101.96 \pm 0.47 \mathrm{cE}$ \\
& 15 & $137.50 \pm 0.99 \mathrm{dF}$ & $109.68 \pm 0.72 \mathrm{bF}$ & $103.47 \pm 1.26 \mathrm{aF}$ & $112.02 \pm 0.50 \mathrm{cF}$ \\
\hline
\end{tabular}

a-d, Means with different letters in each row are significantly different $(P<0.05)$.

A-F, Means with different letters in each column are significantly different $(P<0.05)$. 
The $p$-AnV also increased consistently for every cycles of frying (Table 1 ), and there was a significant $(P<0.05)$ increase in $p$-AnV throughout the whole frying period. $p$-AnV reached a peak in the following order: control $>$ rosemary $>$ BHT $>$ SBT $(P<0.05)$. This was consistent with findings of other studies (Che Man and Jaswir, 2000; Chammem et al., 2015).

Totox value was also obtained to compare the overall oxidative stability of the samples. As shown in Table 1, the Totox value for oil samples subjected to frying increased with the time of frying. Totox values of samples with sea buckthorn, BHT, and rosemary were lower than that of the values measured for the control samples $(P<0.05)$.

3.3.4. Colour analysis. The changes in the colour of the oils during the deep-frying process are shown in Table 2, with $\mathrm{L}^{*}$ as brightness/darkness, $\mathrm{a}^{*}$ greenness/redness, and $\mathrm{b}^{*}$ as an indicator of yellowness/blueness. All treatments decreased $\mathrm{L}^{*}$, indicating darkening of the oil samples with the increase of frying cycles. From a starting value of $L^{*}$ of 58.52 it decreased to 50.89, 53.11, 54.38, and 55.18 after 15 deep-frying cycles for control, BHT, rosemary, and SBT extracts, respectively.

At the same time, the initial $b^{*}$ value of 11.65 increased to $15.99,14.99,14.83$, and 14.56 for control, BHT, rosemary, and SBT extracts, respectively. This is probably due to the presence of natural carotenoids and xanthophylls in the oil (Guo et al., 2016).

Table 2. $\mathrm{L}^{*}, \mathrm{a}^{*}$ and $\mathrm{b}^{*}$ colour values of high oleic sunflower oil samples with different antioxidants

\begin{tabular}{lccccc}
\hline $\begin{array}{l}\text { Colour } \\
\text { values }\end{array}$ & Cycles & Control & BHT & Sea buckthorn & Rosemary \\
\hline $\mathrm{L}^{*}$ & 0 & $58.52 \pm 0.54 \mathrm{aF}$ & $58.52 \pm 0.54 \mathrm{aE}$ & $58.52 \pm 0.54 \mathrm{aE}$ & $58.52 \pm 0.54 \mathrm{aE}$ \\
& 3 & $57.11 \pm 0.50 \mathrm{aE}$ & $57.82 \pm 0.53 \mathrm{bDE}$ & $58.29 \pm 0.56 \mathrm{dDE}$ & $58.25 \pm 0.57 \mathrm{cDE}$ \\
& 6 & $55.41 \pm 0.28 \mathrm{aD}$ & $56.97 \pm 0.12 \mathrm{bCD}$ & $57.62 \pm 0.29 \mathrm{dCD}$ & $57.55 \pm 0.47 \mathrm{cCD}$ \\
& 9 & $54.68 \pm 0.22 \mathrm{aC}$ & $55.78 \pm 0.90 \mathrm{bC}$ & $57.12 \pm 0.56 \mathrm{dBC}$ & $56.84 \pm 0.02 \mathrm{cC}$ \\
& 12 & $53.32 \pm 0.13 \mathrm{aB}$ & $54.22 \pm 0.24 \mathrm{bB}$ & $55.62 \pm 0.43 \mathrm{cAB}$ & $55.95 \pm 0.60 \mathrm{~dB}$ \\
& 15 & $50.89 \pm 0.56 \mathrm{aA}$ & $53.11 \pm 0.36 \mathrm{bA}$ & $55.18 \pm 0.30 \mathrm{dA}$ & $54.38 \pm 0.12 \mathrm{cA}$ \\
$\mathrm{a}^{*}$ & -3.63 & -5.41 & -3.34 & -4.14 \\
& 0 & $-3.55 \pm 0.25 \mathrm{aA}$ & $-3.55 \pm 0.25 \mathrm{aA}$ & $-3.55 \pm 0.25 \mathrm{aA}$ & $-3.55 \pm 0.25 \mathrm{aA}$ \\
& 3 & $-3.30 \pm 0.10 \mathrm{aAB}$ & $-3.25 \pm 0.00 \mathrm{cB}$ & $-3.25 \pm 0.12 \mathrm{cB}$ & $-3.27 \pm 0.20 \mathrm{bB}$ \\
& 6 & $-3.19 \pm 0.25 \mathrm{dBC}$ & $-3.22 \pm 0.11 \mathrm{aB}$ & $-3.22 \pm 0.11 \mathrm{bB}$ & $-3.23 \pm 0.11 \mathrm{bC}$ \\
& 9 & $-3.13 \pm 0.68 \mathrm{bBC}$ & $-3.12 \pm 0.06 \mathrm{cC}$ & $-3.14 \pm 0.37 \mathrm{aC}$ & $-3.13 \pm 0.20 \mathrm{bD}$ \\
& 12 & $-2.90 \pm 0.32 \mathrm{dC}$ & $-3.03 \pm 0.11 \mathrm{bD}$ & $-3.06 \pm 0.05 \mathrm{aD}$ & $-3.00 \pm 0.17 \mathrm{dE}$ \\
$\mathrm{b}^{*}$ & 15 & $-2.55 \pm 0.38 \mathrm{dD}$ & $-2.93 \pm 0.21 \mathrm{dE}$ & $-3.01 \pm 0.15 \mathrm{aE}$ & $-2.94 \pm 0.21 \mathrm{bF}$ \\
& Change & 1.01 & 0.63 & 0.52 & 0.62 \\
& 0 & $11.65 \pm 0.20 \mathrm{aA}$ & $11.65 \pm 0.20 \mathrm{aA}$ & $11.65 \pm 0.20 \mathrm{aA}$ & $11.65 \pm 0.20 \mathrm{aA}$ \\
& 3 & $12.03 \pm 0.16 \mathrm{dAB}$ & $11.77 \pm 0.02 \mathrm{bA}$ & $11.73 \pm 0.25 \mathrm{aAB}$ & $11.82 \pm 0.07 \mathrm{cA}$ \\
& 6 & $12.38 \pm 0.14 \mathrm{~dB}$ & $12.26 \pm 0.42 \mathrm{cB}$ & $11.96 \pm 0.01 \mathrm{aB}$ & $12.24 \pm 0.34 \mathrm{bB}$ \\
& 9 & $13.63 \pm 0.96 \mathrm{dC}$ & $13.00 \pm 0.65 \mathrm{cC}$ & $12.81 \pm 0.25 \mathrm{bC}$ & $12.81 \pm 0.66 \mathrm{aC}$ \\
& 12 & $15.15 \pm 0.26 \mathrm{dD}$ & $13.71 \pm 0.15 \mathrm{aD}$ & $13.72 \pm 0.34 \mathrm{bD}$ & $13.77 \pm 0.11 \mathrm{cD}$ \\
& 15 & $15.99 \pm 0.49 \mathrm{dE}$ & $14.83 \pm 0.03 \mathrm{bE}$ & $14.56 \pm 0.04 \mathrm{aE}$ & $14.99 \pm 0.10 \mathrm{cE}$ \\
& Change & 4.34 & 3.18 & 2.91 & 3.34 \\
\hline
\end{tabular}

$\mathrm{a}-\mathrm{d}$, Means with different letters in each row are significantly different $(P<0.05)$.

A-F, Means with different letters in each column are significantly different $(P<0.05)$. 


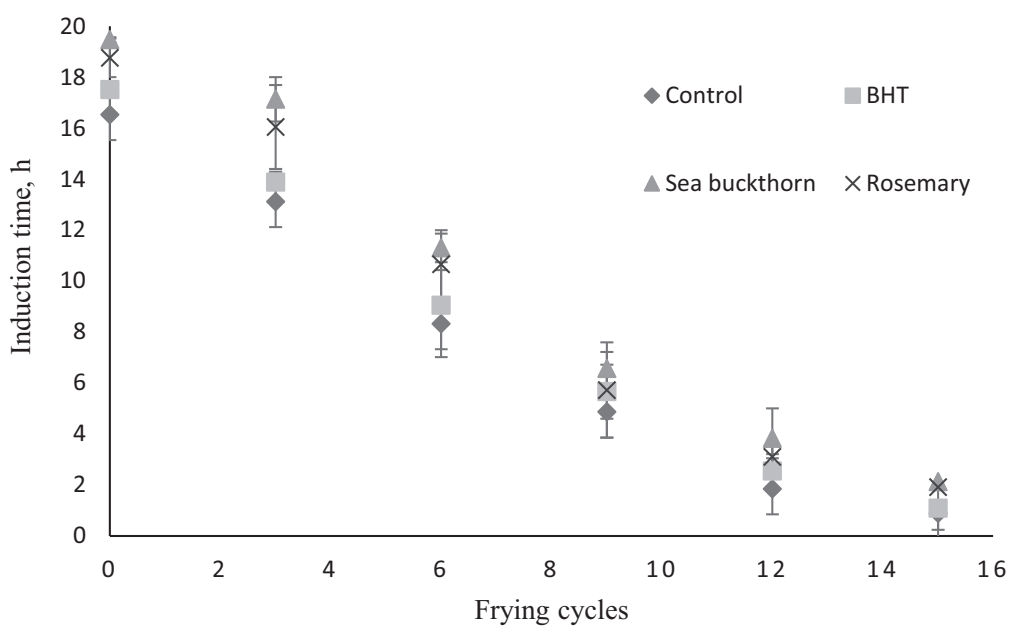

Fig. 3. Changes in the induction time of high oleic sunflower oil samples with different antioxidants during frying

Finally, there was also a significant $(P<0.05)$ increase in a* values. The results were similar to those obtained for the peroxide content, which reflected a continuous change in the frying oil. Therefore, the samples with no antioxidants changed more dramatically than those containing BHT, rosemary, and sea buckthorn.

3.3.5. Induction time. The result showed that SBT and rosemary significantly $(P<0.05)$ improved the resistance to oxidative rancidity of frying oils in the first 6 cycles of the frying, and the effect gradually decreased till the end of frying cycles (Fig. 3). After the $6^{\text {th }}$ cycle, the oxidative rancidity of frying oils with or without antioxidants seemed to get closer to each other during continuous heating with further deterioration of antioxidants. This observation is in accordance with the study of Yang et al. (2016).

\section{CONCLUSION}

The present study has revealed that SBT extract exhibited the strongest scavenging activity and effectively slows oil deterioration during frying. In terms of TPCs, FFAs, $p$-AnV, Totox value, TPC, rancidity, and colour $\left(L^{*}, a^{*}, b^{*}\right)$, the data showed that the oil treated with SBT extract had higher oxidative stability compared to the control oil and the oil with other natural and synthetic antioxidants. Natural extract at the concentration of $400 \mathrm{ppm}$ showed considerable antioxidative effects with minimal consumption of antioxidants. Overall, this is a preliminary report on the extraction and antioxidant capacity from SBT, and further studies are needed for the identification of individual phenolic components to explain the mechanisms underlying its antioxidant properties and the existence of possible synergism, if any, among different phenolic compounds. 


\section{ACKNOWLEDGEMENTS}

The authors are grateful to the Doctoral School of Food Sciences, the Hungarian University of Agriculture and Life Sciences. The project was supported by the European Union and co-financed by the European Social Fund (grant agreement no. EFOP-3.6.3-VEKOP-16-201700005).

\section{SUPPLEMENTARY MATERIAL}

Supplementary data to this article can be found online at https://doi.org/10.1556/066.2021. 00080.

\section{REFERENCES}

AOCS. (1998). Official methods and recommended practices of the American Oil Chemist's Society ( $5^{\text {th }}$ ed., Vol. 1). AOCS Press, Chicago.

Benzie, I. and Strain, L. (1996). Ferric reducing ability of plasma (FRAP) as a measure of antioxidant power: the FRAP assay. Analytical Biochemistry, 239: 70-76.

Chammem, N., Saoudi, S., Sifaoui, I., Sifi, S., de Person, M., Abderraba, M., and Hamdi, M. (2015). Improvement of vegetable oils quality in frying conditions by adding rosemary extract. Industrial Crops and Products, 74: 592-599.

Che Man, Y.B. and Jaswir, I. (2000). Effect of rosemary and sage extracts on frying performance of refined, bleached and deodorized (RBD) palm oil during deep-fat frying. Food Chemistry, 69, 301307.

Da Porto, C., Porretto, E., and Decorti, D. (2013). Comparison of ultrasound-assisted extraction with conventional extraction methods of oil and polyphenols from grape (Vitis vinifera L.) seeds. Ultrasonics Sonochemistry, 20(4): 1076-1080.

Erkan, N., Ayranci, G., and Ayranci, E. (2008). Antioxidant activities of rosemary (Rosmarinus officinalis) extract, blackseed (Nigella sativa) essential oil, carnosic acid, rosmarinic acid and sesamol. Food Chemistry, 110(1): 76-82.

Firestone, D. (2009). Official methods and recommended practices of the American Oil Chemists' Society ( $6^{\text {th }}$ ed.), Champaign, IL, USA.

Guo, Q., Gao, S., Sun, Y., Gao, Y., Wang, X., and Zhang, Z. (2016). Antioxidant efficacy of rosemary ethanol extract in palm oil during frying and accelerated storage. Industrial Crops and Products, 94: $82-88$.

Hou, D.X. (2003). Potential mechanisms of cancer chemoprevention by anthocyanins. Current Molecular Medicine: 3(2): 149-159.

Kant, V., Madhuri, M., and Varshneya, C. (2012), Antioxidant potential and total phenolic contents of seabuckthorn (Hippophae rhamnoides) pomace. Free Radicals and Antioxidants, 2(4): 79-86.

Liu, X., Ardo, S., Bunning, M., Parry, J., Zhou, K., Stushnoff, C., and Kendall, P. (2007). Total phenolic content and DPPH radical dot radical scavenging activity of lettuce (Lactuca sativa L.) grown in Colorado. LWT - Food Science and Technology, 40(3): 552-557. 
Negi, P.S., Chauhan, A.S., Sadia, G.A, Rohinishree, Y.S., and Ramteke, R.S. (2005). Antioxidant and antibacterial activities of various seabuckthorn (Hippophae rhamnoides L.) seed extracts. Food Chemistry, 92(1): 119-124.

Papuc, C., Diaconescu, C., Nicorescu, V., and Crivineanu, C. (2008). Antioxidant activity of polyphenols from sea buckthorn fruits (Hippophae rhamnoides). Revista de Chimie, 59(4): 392-394.

Poiana, M.-A. (2012). Enhancing oxidative stability of sunflower oil during convective and microwave heating using grape seed extract. International Journal of Molecular Sciences, 13(7): 9240-9259.

Rodríguez-Rojo, S., Visentin, A., Cocero, M.J., and Maestri, D. (2012). Assisted extraction of rosemary antioxidants with green solvents. Journal of Food Engineering, 109(1): 98-103.

Shahidi, F. and Ambigaipalan, P. (2015). Phenolics and polyphenolics in foods, beverages and spices: antioxidant activity and health effects, a review. Journal of Functional Foods, 18(Part B): 820-897.

Singleton, V., Orthofer, R., and Lamuela-Raventos, R. (1999). Analysis of total phenols and other oxidation substrates and antioxidants by means of Folin-Ciocalteu reagent. Methods in Enzymology, 299: 152178.

Upadhyay, R. and Mishra, H.N. (2015). Multivariate analysis for kinetic modeling of oxidative stability and shelf life estimation of sunflower oil blended with sage (Salvia officinalis) extract under Rancimat conditions. Food and Bioprocess Technology, 8: 801-810.

Urbančič, S., Kolar, M.H., Dimitrijević, D., Demšar, L., and Vidrih, R. (2014). Stabilisation of sunflower oil and reduction of acrylamide formation of potato with rosemary extract during deep-fat frying. $L W T-$ Food Science and Technology, 57(2): 671-678.

Wu, G., Chang, C., Hong, C., Zhang, H., Huang, J., Jin, Q., and Wang, X. (2019). Phenolic compounds as stabilizers of oils and antioxidative mechanisms under frying conditions: a comprehensive review. Trends in Food Science \& Technology, 92: 33-45.

$\mathrm{Xu}, \mathrm{B}$. and Chang, S. (2007). A comparative study on phenolic profiles and antioxidant activities of legumes as affected by extraction solvents. Journal of Food Science, 72: S159-S166.

Yang, Y., Song, X., Sui, X., Qi, B., Wang, Z., Li, Y., and Jiang, L. (2016). Rosemary extract can be used as a synthetic antioxidant to improve vegetable oil oxidative stability. Industrial Crops and Products, 80: 141-147.

Open Access. This is an open-access article distributed under the terms of the Creative Commons Attribution 4.0 International License (https://creativecommons.org/licenses/by/4.0/), which permits unrestricted use, distribution, and reproduction in any medium, provided the original author and source are credited, a link to the CC License is provided, and changes - if any - are indicated. (SID_1) 